\title{
Productivity in seeds of the green bean produced under conventional and organic systems ${ }^{1}$
}

\section{Produtividade de sementes de feijão-vagem produzidas sob sistemas convencional e orgânico}

\author{
Ruanny Karen Vidal Pantoja Portal ${ }^{2 *}$; Warley Marcos Nascimento ${ }^{3}$; Valdivina \\ Lúcia Vidal'; ${ }^{4}$ Marcos Coelho ${ }^{4}$; Nei Peixoto ${ }^{5}$
}

\begin{abstract}
Two experiments were carried out during 2016 at the Anápolis Experimental Station of EMATER in the State of Goiás, with the aim of studying the yield of seeds of 18 strains and two indeterminate cultivars of the green bean, one experiment under a conventional system and the other under an organic system. A randomized block experimental design was used, with twenty treatments and three replications, to evaluate the mean number of seeds per pod (NSP), 100-seed weight (100SW) and productivity (PROD). Under the conventional system, the $100 \mathrm{SW}$ ranged from 19.3 to 25.0 grams. The highest productivity was achieved with the UEG 0212, UEG 0212, UEG 0712 and UEG 3014 strains, which were superior to the other strains, including the controls. Under the organic system, there was a range of 6.66 to 8.33 for the NSP, while for the 100SW, the range was from 23 to 32 grams. The UEG 0212, UEG 1012, UEG 2014 and UEG 3014 strains, all with cylindrical pods and white seeds, can be used as alternatives for planting, being superior to the 'Favorito' cultivar and equal to the 'Macarrão Bragança' cultivar, whereas UEG 1112 and UEG 0714, with cylindrical pods and cream-colored seeds, can be used as dual-adapted cultivars, with green pods and dry grain that can be used as end-of-cycle pods if there are defects that are not accepted by the market. ${ }^{2}$
\end{abstract}

Key words: Phaseolus vulgaris L. Yield. Genotype evaluation. Conventional farming. Organic farming.

\section{Resumo}

Com o objetivo de estudar o rendimento de sementes de 18 linhagens e duas cultivares de crescimento indeterminado de feijão-vagem, dois experimentos foram conduzidos em 2016, na Estação Experimental de Anápolis, EMATER-Goiás, sendo um em sistema convencional e outro em orgânico. Utilizou-se o delineamento experimental de blocos casualizados, com vinte tratamentos e três repetições, avaliando, número médio de sementes por vagem (NSV), massa de 100 sementes (M100S) e produtividade (PROD). No sistema convencional a M100S teve amplitude de 19,3 a 25,0 gramas. As maiores produtividades foram alcançadas pelas linhagens UEG 0212, UEG 0212, UEG 0712e UEG 3014 superando as demais,

1 Parte da dissertação de mestrado do primeiro autor.

2 Discente, Curso de Doutorado do Programa de Pós-Graduação em Biodiversidade e Biotecnologia da Rede Bionorte, Universidade Federal do Pará, UFPA, Campus Belém, Belém, PA, Brasil. E-mail: ruanny_vidal@hotmail.com

3 Pesquisador, Empresa Brasileira de Pesquisa Agropecuária, EMBRAPA Hortaliças, Brasília, DF, Brasil. E-mail: warley. nascimento@embrapa.br

4 Pesquisadores, Estação Experimental de Anápolis, Agência Goiana de Assistência Técnica, Extensão Rural e Pesquisa Agropecuária-EMATER, Anápolis, GO. E-mail: luciavidalc@yahoo.com.br; mcoelho@emater.go.gov.br

5 Prof., Programa de Pós-Graduação em Produção Vegetal, Universidade Estadual de Goiás, UEG, Câmpus Ipameri, Ipameri, GO, Brasil. E-mail: nei.peixoto48@gmail.com

* Author for correspondence 
inclusive, as testemunhas. No sistema orgânico, houve uma amplitude de 6,66 a 8,33 para NSV; para M100S a amplitude foi de 23 a 32 gramas. As linhagens UEG 0212, UEG 1012, UEG 2014 e UEG 3014 , todas com vagens cilíndricas e sementes brancas podem ser indicadas como alternativa de plantio, pois superaram a cultivar Favorito e igualaram com Macarrão Bragança, enquanto que UEG 1112 e UEG 0714, com vagens cilíndricas e sementes creme, podem ser utilizadas como cultivares de dupla aptidão, vagens verdes e grãos secos, principalmente utilizando-se as vagens de final de ciclo que, em qualquer cultivar, apresentam defeitos que não são aceitos, como hortaliça, pelo mercado.

Palavras-chave: Phaseolus vulgaris L. Rendimento. Avaliação de genótipos. Agricultura convencional. Agricultura orgânica.

\section{Introduction}

Despite the large consumption of green beans in Brazil, there are few cultivars available to producer today. In organic systems, this lack of cultivars is more evident, hence the need to develop cultivars for the various production systems.

According to Peixoto and Cardoso (2016), consumers consider health as the main reason for consuming organic products since they are free of pesticides. According to Souza and Resende (2006), organic farming can be defined as a production system where techniques and methods that are not aggressive to the environment are used during the production process. In addition to excluding the use of chemical pesticides, various other products are not used, such as chemical fertilizers that could leave residues in the food or degrade the soil, water and other components of the environment. In relation to the world market, there is a growing demand for food produced with fewer chemical products and that are less harmful to the environment, and this trend, according to Buainain and Batalha (2007), is also reflected in Brazil. Brazil ranks 10th among countries with large amounts of land devoted to organic farming, with 705 thousand hectares (IFOAM, 2014). However, when compared to conventional production systems, this system, even in a growing market, is still new.

According to Nascimento et al. (2011), together with pioneering organic production, the vegetable sector faces several problems. One problem is the lack of organic seeds available; thus, producers have to resort to seeds produced under conventional systems. Additionally, the volume demanded today is low, discouraging seed companies from investing in this segment of the market.

Currently, there are several studies involving vegetables grown under organic systems; important among them is the green bean (Phaseolus vulgaris L.). Peixoto and Cardoso (2016) state that this crop is not difficult to establish when grown under an organic system. The green bean is a vegetable that differs from the common bean only at the podharvesting stage, which takes place when the pods are still immature and can be used for food, both industrially and in natura (HAESBAERT et al., 2011). Additionally, the pods are larger and have a low fiber content (PEIXOTO; CARDOSO, 2016).

The green bean is among the ten most produced vegetables in Brazil and is an important income component in family farming (PEIXOTO; CARDOSO, 2016).

The main characteristics of green bean cultivars, according to Teixeira et al. (2004), are the growth habit and the color and type of pod. The growth habit is one of the most important characteristics for classification and can be classified as indeterminate or determinate.

In Brazil, production is carried out mainly by family farmers using a training system (PEIXOTO; CARDOSO, 2016), which produces pods for longer periods and achieves higher yields. The share of vegetable seeds for indeterminate green beans was $86,849.09 \mathrm{~kg}$ (ABCSEM, 2009), with a mean domestic yield of 2,000 $\mathrm{kg} \mathrm{ha}^{-1}$ (MARTINS et al., 2014). 
The aim of this work was to study the development and yield of seeds of 20 green bean genotypes of indeterminate growth under conventional and organic systems in the field.

\section{Materials and Methods}

Two experiments were carried out from May to August 2016 at the Anápolis Experimental Station of the company for Technical Assistance and Rural Extension of Goiás, located at $16^{\circ} 19^{\prime} 48^{\prime \prime} \mathrm{S}$ and $48^{\circ} 58^{\prime} 23^{\prime}$ ' $\mathrm{W}$ and at an average altitude of $1,030 \mathrm{~m}$. The climate is classified as AW (Köppen) with two well-defined seasons (dry and rainy), with periods of drought during the rainy season (short, dry spells).

The experiment under the conventional system (Area 1) was located at a distance of 500 meters from the experiment carried out under the organic system, which had been adopted in Area 2 for over 15 years. According to Embrapa (2013), the soil is classified as a red latosol of a clayey texture. A chemical analysis of the soil was carried out for both areas, with the results for Area 1 as follows: $\mathrm{pH}$ in $\mathrm{CaCl}_{2}=4.8$, available $\mathrm{P}$ (Mehlich 1 extractor $)=$ $2.7 \mathrm{cmol} \mathrm{dm}^{-3}$, available $\mathrm{K}=64.2 \mathrm{mg} \mathrm{dm}^{-3}, \mathrm{Ca}+\mathrm{Mg}$ $=2.43 \mathrm{cmol} \mathrm{dm}^{-3}, \mathrm{Al}=0.2 \mathrm{cmol} \mathrm{dm}^{-3}$ and organic matter $=24 \mathrm{~g} \mathrm{dm}^{-3}$. The soil analysis results for Area 2 were as follows: $\mathrm{pH}$ in $\mathrm{CaCl}_{2}=5.2$, available $\mathrm{P}$ (Mehlich 1 extractor) $=6.4 \mathrm{cmol} \mathrm{dm}^{-3}$, available $\mathrm{K}$ $=107.0 \mathrm{mg} \mathrm{dm}^{-3}, \mathrm{Ca}+\mathrm{Mg}=2.89 \mathrm{cmol} \mathrm{dm}^{-3}, \mathrm{Al}$ $=0.0 \mathrm{cmol} \mathrm{dm}^{-3}$ and organic matter $=30.0 \mathrm{~g} \mathrm{dm}^{-3}$. Area 2 is managed according to Law 10.831, which regulates organic farming in Brazil (MAPA, 1999; BRASIL, 2003).

In both experiments, the experimental design usedrandomized blocks with twenty treatments and three replications. The plots comprised two rows of plants, 3.00 meters long, with two plants per hole, arranged at a spacing of $1.00 \mathrm{~m} \times 0.30 \mathrm{~m}$ and trained using plastic tape.

The treatments consisted of 18 strains of indeterminate growth green bean obtained from the breeding program of UEG, Ipameri Campus, and the 'Favorito' and 'Bragança Macaroni' commercial cultivars were used as controls (Table 1).

Table 1. Characteristics of green bean genotypes grown under conventional and organic systems.

\begin{tabular}{cccc}
\hline Genotype & Flower color & Pod shape & Seed color \\
Favorito & White & Cylindrical & White \\
Macarrão Bragança & White & Cylindrical & White \\
UEG 0212 & White & Cylindrical & White \\
UEG 0412 & White & Cylindrical & White \\
UEG 0612 & White & Elongated & White \\
UEG 0712 & White & Cylindrical & White \\
UEG 0812 & Lilac & Cylindrical & Light cream \\
UEG 0912 & Lilac & Cylindrical & Light cream \\
UEG 1012 & White & Cylindrical & White \\
UEG 1112 & White & Cylindrical & Dark cream \\
UEG 1212 & White & Cylindrical & Dark cream \\
UEG 1312 & Lilac & Cylindrical & Light cream \\
UEG 3512 & White & Cylindrical & White \\
UEG 3913 & White & Cylindrical & Dark cream
\end{tabular}


continuation

\begin{tabular}{lccc} 
UEG 0714 & Lilac & Cylindrical & Light cream \\
UEG 0914 & Lilac & Cylindrical & Light cream \\
UEG 2014 & Lilac & Cylindrical & White \\
UEG 2514 & White & Cylindrical & Light cream \\
UEG 2914 & Lilac & Cylindrical & Medium cream \\
UEG 3014 & White & Cylindrical & White \\
\hline
\end{tabular}

In both experiments, sowing took place on 2 May 2016, with four seeds being sown per hole. The plants were later thinned, leaving only two plants. The plants were trained with tape and supported by wire fixed to the top of wooden poles and stakes.

The water requirements of the crop were supplied by sprinkler irrigation. Watering stopped when $70 \%$ of the pods showed signs of physiological maturation, characterized in both experiments by a change in color and the start of pod drying. Other crop and phytosanitary treatments were carried out according to the needs of the crop and to the production system adopted.

\section{Conventional production system}

Fertilization was carried out using $1,000 \mathrm{~kg} \mathrm{ha}^{-1}$ NPK 2-20-18 formula at sowing, with $300 \mathrm{~kg} \mathrm{ha}^{-1}$ ammonium sulfate applied as a top dressing 20 days after sowing. Weed control was by a herbicide with fluazifop-p-butyl as an active ingredient. The cucurbit beetle (Diabrotica speciosa) and whitefly (Bemisia tabaci) were controlled with three sprayings using the active ingredients imidacloprid, deltamethrin and carbaryl, respectively; the doses were as recommended by the manufacturer.

\section{Organic production system}

Fertilization was carried out at sowing following earlier unpublished experiments, using $5,000 \mathrm{~kg}$ $\mathrm{ha}^{-1}$ of the organic compound produced at the same institution from corn straw and pure chicken manure, as per the methodology of Souza and Resende (2003). In addition, $300 \mathrm{~kg} \mathrm{ha}^{-1}$ of Yoorin thermophosphate was used as organic phosphorus at sowing, and 2,000 $\mathrm{kg} \mathrm{ha}^{-1}$ of the organic compound was used as a top-dressing fertilizer. Chemical analysis of the organic compound showed the following composition: $\mathrm{pH}$ in water $=6.69, \mathrm{~K}=8.0$ $\mathrm{g} \mathrm{kg}^{-1}, \mathrm{~N}=14.0 \mathrm{~g} \mathrm{~kg}^{-1}, \mathrm{P}=22.0 \mathrm{~g} \mathrm{~kg}^{-1}$ and organic matter $=200.0 \mathrm{~g} \mathrm{~kg}^{-1}$.

During the crop cycle, three sprayings of neem oil and biofertilizer, at a dose of one milliliter neem oil per liter of water, were used to control cucurbit beetle (Diabrotica speciosa) and whitefly (Bemisia tabaci), with $500 \mathrm{ml}$ of liquid Bokashi ${ }^{\circledR}$ per 100 liters of water, as per the manufacturer's recommendation.

The crop cycle from sowing to harvesting was 120 days for all genotypes under both of the adopted cropping systems. At harvesting, under both systems, the plants were pulled up and threshed, and the following data were obtained: the mean number of seeds per pod, 100-seed weight and seed productivity.

For the joint analysis of the data from the experiment, the following linear model was adopted:

$$
y_{i j l}=\not l+b_{j}+t_{i}+t_{l}^{*}+c_{i j}+e_{i j l}
$$

where $\mathrm{i}=1,2, \ldots, \mathrm{V}$ represents primary treatments (conventional and organic systems); $\mathrm{j}=1,2, \ldots, \mathrm{b}$ represents blocks; $1=1,2, \ldots, \mathrm{u}$ represents secondary treatments (genotypes); $\mathrm{y}_{\mathrm{ijl}}$ is the value observed in the subplot corresponding to the i-th secondary 
treatment, within the i-th primary treatment, in the $\mathrm{j}$-th block; $\mathrm{m}$ is a constant representing the overall mean; $b_{j}$ is the effect of the $j$-th block; $t_{i}$ is the effect of the $i$-th primary treatment; $t_{1}$ is the effect of the 1-th secondary treatment; $d_{i l}$ is the effect of the interaction between the $\mathrm{i}$-th primary treatment and the 1-th secondary treatment; $\mathrm{e}_{\mathrm{ijl}}$ is the random error assigned to observation $\mathrm{y}_{\mathrm{ijl}}$ and is considered the residual component. The data were submitted to analysis of variance, and the mean values compared by the Scott-Knott test at $5 \%$ probability using
SISVAR software (FERREIRA, 2011).

\section{Results and Discussion}

There was a significant interaction between genotype and cropping system for seed productivity only. The results for the mean number of seeds per pod, mean 100-seed weight and seed productivity in the bean genotypes obtained under conventional and organic cultivation are shown in Table 2.

Table 2. Mean number of seeds per pod (NSP), mean 100-seed weight (100SW) and seed productivity (PROD) in green bean genotypes grown under conventional and organic systems. Anápolis, Goiás, 2016.

\begin{tabular}{ccccccc}
\hline \multirow{2}{*}{ Genotype } & \multicolumn{2}{c}{ NSP $^{\text {ns }}$} & \multicolumn{2}{c}{100 SW $^{\text {ns }}$} & \multicolumn{2}{c}{${\text { PROD }\left(\mathrm{kg}^{-1} \mathrm{a}^{-1}\right) * *}^{* *}$} \\
\cline { 2 - 7 } & Conventional & Organic & Conventional & Organic & Conventional & Organic \\
\hline Favorito & $6.93 \mathrm{a}$ & $6.60 \mathrm{~b}$ & $21.44 \mathrm{~b}$ & $26.59 \mathrm{~b}$ & $538.89 \mathrm{~b}$ & $1227.77 \mathrm{a}$ \\
Macarrão Bragança & $7.66 \mathrm{a}$ & $8.00 \mathrm{a}$ & $24.65 \mathrm{a}$ & $30.71 \mathrm{a}$ & $1277.77 \mathrm{a}$ & $1444.44 \mathrm{a}$ \\
UEG 0212 & $8.33 \mathrm{a}$ & $8.30 \mathrm{a}$ & $25.14 \mathrm{a}$ & $27.32 \mathrm{a}$ & $1550.00 \mathrm{a}$ & $1216.67 \mathrm{a}$ \\
UEG 0412 & $8.10 \mathrm{a}$ & $7.96 \mathrm{a}$ & $24.06 \mathrm{a}$ & $30.64 \mathrm{a}$ & $833.33 \mathrm{~b}$ & $1070.55 \mathrm{a}$ \\
UEG 0612 & $7.66 \mathrm{a}$ & $7.76 \mathrm{a}$ & $22.44 \mathrm{~b}$ & $28.91 \mathrm{a}$ & $1127.77 \mathrm{~b}$ & $1483.33 \mathrm{a}$ \\
UEG 0712 & $7.63 \mathrm{a}$ & $8.20 \mathrm{a}$ & $24.80 \mathrm{a}$ & $31.75 \mathrm{a}$ & $1322.22 \mathrm{a}$ & $1200.00 \mathrm{a}$ \\
UEG 0812 & $7.86 \mathrm{a}$ & $8.10 \mathrm{a}$ & $20.98 \mathrm{~b}$ & $23.69 \mathrm{~b}$ & $1111.11 \mathrm{~b}$ & $1450.55 \mathrm{a}$ \\
UEG 0912 & $7.96 \mathrm{a}$ & $7.86 \mathrm{a}$ & $20.77 \mathrm{~b}$ & $24.76 \mathrm{~b}$ & $938.89 \mathrm{~b}$ & $1294.44 \mathrm{a}$ \\
UEG 1012 & $8.06 \mathrm{a}$ & $7.83 \mathrm{a}$ & $22.85 \mathrm{a}$ & $28.86 \mathrm{a}$ & $1694.44 \mathrm{a}$ & $1066.66 \mathrm{a}$ \\
UEG 1112 & $7.73 \mathrm{a}$ & $7.30 \mathrm{~b}$ & $20.71 \mathrm{~b}$ & $23.22 \mathrm{~b}$ & $1555.55 \mathrm{a}$ & $772.22 \mathrm{a}$ \\
UEG 1212 & $7.40 \mathrm{a}$ & $7.43 \mathrm{~b}$ & $21.52 \mathrm{~b}$ & $23.07 \mathrm{~b}$ & $822.22 \mathrm{~b}$ & $865.55 \mathrm{a}$ \\
UEG 1312 & $7.93 \mathrm{a}$ & $8.10 \mathrm{a}$ & $19.49 \mathrm{~b}$ & $24.52 \mathrm{~b}$ & $1183.33 \mathrm{~b}$ & $1227.77 \mathrm{a}$ \\
UEG 3512 & $7.63 \mathrm{a}$ & $8.46 \mathrm{a}$ & $21.62 \mathrm{~b}$ & $29.61 \mathrm{a}$ & $611.11 \mathrm{~b}$ & $1483.33 \mathrm{a}$ \\
UEG 3913 & $7.76 \mathrm{a}$ & $7.26 \mathrm{~b}$ & $20.81 \mathrm{~b}$ & $23.28 \mathrm{~b}$ & $1219.44 \mathrm{~b}$ & $977.77 \mathrm{a}$ \\
UEG 0714 & $8.10 \mathrm{a}$ & $7.83 \mathrm{a}$ & $21.40 \mathrm{~b}$ & $23.66 \mathrm{~b}$ & $1383.33 \mathrm{a}$ & $1444.44 \mathrm{a}$ \\
UEG 0914 & $7.86 \mathrm{a}$ & $7.83 \mathrm{a}$ & $19.41 \mathrm{~b}$ & $24.54 \mathrm{~b}$ & $816.66 \mathrm{~b}$ & $1327.78 \mathrm{a}$ \\
UEG 2014 & $8.33 \mathrm{a}$ & $8.50 \mathrm{a}$ & $24.74 \mathrm{a}$ & $31.63 \mathrm{a}$ & $1933.33 \mathrm{a}$ & $1661.11 \mathrm{a}$ \\
UEG 2514 & $7.23 \mathrm{a}$ & $6.90 \mathrm{~b}$ & $21.80 \mathrm{~b}$ & $25.53 \mathrm{~b}$ & $1061.11 \mathrm{~b}$ & $811.11 \mathrm{a}$ \\
UEG 2914 & $7.20 \mathrm{a}$ & $7.10 \mathrm{~b}$ & $22.81 \mathrm{a}$ & $25.43 \mathrm{~b}$ & $1099.99 \mathrm{~b}$ & $960.00 \mathrm{a}$ \\
UEG 3014 & $8.26 \mathrm{a}$ & $8.30 \mathrm{a}$ & $24.37 \mathrm{a}$ & $29.94 \mathrm{a}$ & $1655.55 \mathrm{a}$ & $1500.00 \mathrm{a}$ \\
\hline CV (\%) Genotypes & & 26.16 & & 12.31 & & 15.25 \\
CV (\%) Systems & & 6.53 & & 8.09 & & 29.29 \\
\hline
\end{tabular}

Mean values followed by the same letter in a row and a column do not differ by Scott-Knott Test at 5\% probability. 
For the number of seeds per pod, the genotypes were statistically equivalent under the conventional cropping system, but under the organic system, the 'Macarrão Bragança' cultivar and the UEG 0212, UEG 0412, UEG 0612, UEG 0712, UEG 0812, UEG 0912, UEG 1012, UEG 1312, UEG 3512, UEG 0714, UEG 0914, UEG 2014 and UEG 3014 strains achieved the highest mean values, surpassing the 'Favorito' cultivar and the remaining strains. Even the lowest values found were higher than those achieved by Fonte et al. (2012), who evaluated the production of bush bean seeds under an organic system and reported mean values of between 3.5 and 4.0 seeds per pod, probably because they used the 'Dutch' commercial type, which, according to Peixoto and Cardoso (2016), has a smaller pod.

The 'Macarrão Bragança' cultivar and the UEG 0212, UEG 0412, UEG 0612, UEG 0712, UEG 1012, UEG 2014, UEG 2914 and UEG 3014 strains had the greatest 100-seed weight under the conventional system, while the 'Favorito' cultivar and the remaining strains had the lowest mean values. For the results under the organic system, the genotypes were divided into two groups, one of larger size, which included the 'Macarrão Bragança' cultivar and seven strains, and the other of smaller size consisting of the 'Favorito' cultivar and the UEG 0212, UEG 0812, UEG 0912, UEG 1112, UEG 1212, UEG 1312, UEG 3913, UEG 0714, UEG 0914, UEG 2514 and UEG 2914 strains. In this regard, all the strains showed equal or superior performance to the cultivars used as controls. It should be noted that greater values for 100 -seed weight positively affect initial vigor. Contrasting data were reported by Peixoto et al. (2002) when studying genetic divergence among another 20 green bean genotypes of indeterminate growth in Anápolis, Goiás, under a traditional cropping system, where the 'Macarrão Bragança' cultivar, also used as a control, showed different behavior and was included in the less-heavy seed group (32.8 g) that produced the smallest seeds; in this study, the cultivar was included among the group having the largest seeds (24.66 g). In the study by Peixoto et al. (2002), using the same cultivars as controls, the genotypes under evaluation had mean values of 31.4 to 42.7 grams, much higher than those obtained in this study, where the range was from 19.33 to 25.00 grams per 100 seeds, showing that this variable is affected by environmental factors. Abreu et al. (2004), using experimental strains, found a range of 15.57 to 39.74 grams in green bean accessions of indeterminate growth.

The results for seed productivity were significant for the interaction between genotype and cropping system and for genotype alone, suggesting that there are genotypes adapted to each cropping system.

The most productive genotypes under the conventional system were the 'Macarrão Bragança' cultivar and the UEG 0212, UEG 0712, UEG 1012, UEG 1112, UEG 0714, UEG 2014 and UEG 3014 strains, while under the organic system, there was no significant difference between genotypes. These values were lower than those obtained by Peixoto et al. (2002), who achieved yields varying from 2.55 to $4.29 \mathrm{t} \mathrm{ha}^{-1}$, a result that is consistent with the result for 100-seed weight. On the other hand, Francelino et al. (2011), evaluating green beans of indeterminate growth under a conventional cropping system in two areas in the north and northwest of the State of Rio de Janeiro, found seed productivity ranging from $910.6 \mathrm{~kg} \mathrm{ha}^{-1}$ to $2692.0 \mathrm{~kg} \mathrm{ha}^{-1}$. These results were similar to those obtained by Vidal et al. (2007), who showed mean values for productivity in shrub beans under an organic system of from 2,300 to $1,300 \mathrm{~kg} \mathrm{ha}^{-1}$, and higher than the data of Pereira et al. (2015), who obtained a productivity in the common bean of $1,839 \mathrm{~kg} \mathrm{ha}^{-1}$ after applying doses of organic fertilizer. The greater productivity found under the organic system, although not differing from the conventional system, may be related to the physical and chemical conditions of the soil and fertilization of the crop in an area that has been managed for more than a decade under an organic system. 


\section{Conclusion}

Among the strains evaluated, UEG 0212, UEG 1012, UEG 2014 and UEG 3014, all with cylindrical pods and white seeds, can be used as alternatives for planting, being superior to the 'Favorito' cultivar and equal to the 'Macarrão Bragança', whereas UEG 1112 and UEG 0714, with cylindrical pods and cream-colored seeds, can be used as dual-adapted cultivars, with green pods and dry grain that can be used as end-of-cycle pods if there are defects that are not accepted by the market.

\section{Acknowledgements}

The authors wish to thank the Coordination for the Improvement of Higher Level Personnel (CAPES) for their support and for the master's scholarship. The authors would also like to thank the Agency for Technical Assistance, Rural Extension and Agricultural Research of Goiás (EMATER), Anapolis Experimental Station (EEA). Thanks also go to the State University of Goiás for the education and instruction.

\section{References}

ABREU, F. B.; LEAL, N. R.; RODRIGUES, R.; AMARAL JÚNIOR, A. T.; SILVA, D. J. H. Divergência genética entre acessos de feijão-de-vagem de hábito de crescimento indeterminado. Horticultura Brasileira, Vitória da Conquista, v. 22, n. 3, p. 547-552, 2004.

ASSOCIAÇÃO BRASILEIRA E COMÉRCIO DE SEMENTES - ABCSEM. Analise de mercado nacional de sementes de hortaliças. 2009. Disponível em: $<$ http:// www.abcsem.com.br/docs/pesquisa_mercado_2009. pdf >. Acesso em: 28 abr. 2017.

BRASIL. Lei No 10. 831 de 23 de dezembro de 2003. Dispõe sobre agricultura orgânica. Diário Oficial [da] União, Brasília, 23, dezembro, 2003.

BUAINAIN, A. M.; BATALHA, M. O. Cadeia produtiva de produtos orgânicos. Brasília: MAPA, 2007. 108 p.

EMPRESA BRASILEIRA DE PESQUISA AGROPECUÁRIA - EMBRAPA. Centro Nacional de Pesquisa de Solos. Sistema brasileiro de classificação de solos. Rio de Janeiro: EMBRAPA Solos, 2013. v. 3, 353 p.
FEDERAÇÃO INTERNACIONAL DOS MOVIMENTOS DA AGRICULTURA ORGÂNICA - IFOAM. Área de produção de produtos orgânicos no Brasil, 2014. Disponível em: <https://www.ifoam. bio/2017/>. Acesso em: 30 abr. 2017.

FERREIRA, D. F. Sisvar: a computer statistical analysis system. Ciência e Agrotecnologia, Lavras, v. 35, n. 6, p. 1039-1042, nov./dez. 2011.

FONTE, R. N. Produção e qualidade de sementes de feijão-vagem sob cultivo orgânico, na região médio serrana do estado do rio de janeiro. 2012. Dissertação (Mestrado em Ciências) - Universidade Federal Rural do Rio de Janeiro, Rio de Janeiro.

FRANCELINO, F. M. A.; AMARAL GRAVINA, G. de; MANHÃES, C. M. C.; CARDOSO, P. M. R.; ARAÚJO, L. C. de. Avaliação de linhagens de feijão-de-vagem para as regiões Norte e Noroeste Fluminense. Revista Ciência Agronômica, Fortaleza, v. 42, n. 2, p. 554-562, 2011.

HAESBAERT, F.; SANTOS, D.; LÚCIO, A.; BENZ, V.; ANTONELLO, B.; RIBEIRO, A. Tamanho de amostra para experimentos com feijão-de-vagem em 19 diferentes ambientes. Ciência Rural, Santa Maria, v. 41, n. 1, p. 3844, 2011.

MARTINS, C. C.; VIEIRA, R. D.; NASCIMENTO, W. N. Produção de sementes de feijão-vagem. In: NASCIMENTO, W. M. Produção de sementes de hortaliças. Brasília: EMBRAPA, 2014. v. 3, cap. 3, p. 205- 238.

MINISTÉRIO DA AGRICULTURA, PECUÁRIA E ABASTECIMENTO - MAPA. Normalização para a produção de produtos orgânicos. Brasília: MAPA, 1999.

NASCIMENTO, W. M.; VIDAL, M. C.; RESENDE, F. V. Produção de sementes de hortaliças em sistema orgânico. In: NASCIMENTO, W. M. Hortaliças: tecnologia de produção de sementes. Brasília: EMBRAPA, 2011. v. 1, parte 1, p. 61-75.

PEIXOTO, N.; BRAZ, L. T.; BANZATTO, D. A.; MORAES, E. A.; MOREIRA, F. M. Características agronômicas, produtividade, qualidade de vagens e divergência genética em feijão-vagem de crescimento indeterminado. Horticultura Brasileira, Vitória da Conquista, v. 20, n. 3, p. 447-451, 2002.

PEIXOTO, N.; CARDOSO, A. I. I. Feijão-vagem. In: NASCIMENTO, W. M. Hortaliças leguminosas. Brasília: EMBRAPA, 2016. v. 1, cap. 2, p. 61-86.

PEREIRA, L. B.; ARF, O.; SANTOS, N. C. B. dos; OLIVEIRA, A. E. Z. de; KOMURO, L. K. Manejo da adubação na cultura do feijão em sistema de produção orgânico. Pesquisa Agropecuária Tropical, Goiânia, v. 45, n. 1, p. 29-38, 2015. 
SOUZA, J. L.; RESENDE, P. Manual de horticultura orgânica. Viçosa, MG: Aprenda Fácil, 2003. 564 p.

TEIXEIRA, A. B.; AMARAL JÚNIOR, A. T.; RODRIGUES, R.;PEREIRA,T.N.S.;BRESSANSMITH,

R. E. Genetic divergence in snap-bean (Phaseolus vulgaris L.) evaluated by different methodologies. Crop Breeding and Applied Biotechnology, Viçosa, MG, v. 4, n. 1, p. 52-62, 2004.
VIDAL, V. L.; JUNQUEIRA, A. M. R.; PEIXOTO, N.; MORAES, E. A. Desempenho de feijão-vagem arbustivo, sob cultivo orgânico em duas épocas. Horticultura Brasileira, Vitória da Conquista, v. 25, n. 1, p. 10-14, 2007. 